\title{
THE CLINICAL FEATURES OF SCORBUTIC NEURITIS.
}

\author{
By R. M. STEWART, Leavesden.
}

Certain of the so-called deficiency diseases are of considerable interest to the neurologist on account of the frequency with which symptoms of disordered function of the nervous system make their appearance. It is well known that in beri-beri polyneuritis is one of the most constant and striking features, while in pellagra-now under suspicion of being a deficiency disease-signs of posterolateral sclerosis in the spinal cord are equally prominent. The evidence that scurvy is a deficiency disease in the strict sense of the term seems well-nigh unequivocal, yet oddly enough the nervous system is generally considered to show no signs of involvement, or, at the most, to present changes which have only a subsidiary part in the clinical picture. In rare instances hemiplegia and other forms of cerebral palsy have been observed, and Hess ${ }^{1}$ has described cases of infantile scurvy exhibiting cardiac and respiratory symptoms of probably vagal origin, but so far as I am aware sensory and reflex phenomena attributable to a neuritis of the peripheral nerves have not been noted. In these circumstances it may be of some interest to place on record the following notes, which were compiled from a clinical study of $\mathbf{1 5 0}$ cases of scurvy during the late war.

\section{SENSORY PHENOMENA.}

Sensory disturbances, occurring principally in the lower limbs, were found in forty-five patients, none of whom had suffered from recent attacks of malaria, or other infections which favour the development of neuritis.

The subjective phenomena included all degrees of pain and paræsthesia, and although in a certain number of cases numbness or " pins and needles" were the only symptoms complained of, much more often the pains were of a lancinating character, aggravated by warmth, movement, and pressure-even the weight of the bedclothes being sufficient to prevent sleep. It is important to observe that although in some cases the legs were enormously swollen and indurated (see Fig. 1), in others no hæmorrhagic infiltrations could be found, and as in all cases the pains were extremely persistent, and continued to cause much suffering long after the disappearance of the ordinary clinical 
signs of scurvy, their presence could not be due solely to the mechanical effects of hæmorrhages in the tissues of the legs.

The objective sensory changes showed considerable variation, but as a rule anæsthesia was partial, a combination of blunting to tactile stimuli with hyperæsthesia to pinprick and pressure being met with. Occasionally hyperæsthesia extended to other qualities of sensation, and a loss of the power of appreciating the vibrations of a tuning fork was also sometimes

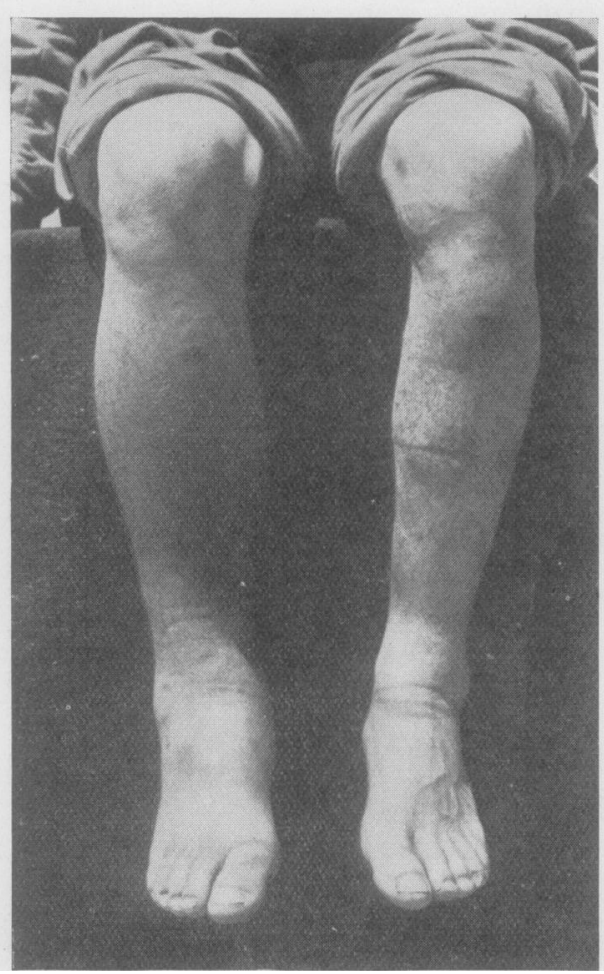

Fig. 1.-Lower limbs in scurvy. Note brawny induration of right leg and subperiosteal hæmorrhages in neighbourhood of left tibia. present. In a few instances pain sensibility was blunted or lost, but thermal sensibility was almost always normal. Disturbance of the sense of position in the toes was noted in three instances, and hyperidrosis on the feet was a common feature; trophic ulcers did not occur.

In not a few cases the peroneal nerves were extremely sensitive to pressure, although actual swelling or thickening of the nerves could not be demonstrated. The calf muscles were usually tender on pressure, and either soft or extremely firm and indurated from the presence of deep-seated hæmorrhage. Although complete motor paralysis was never observed, a certain degree of weakness in the extensor muscles below the knees was occasionally encountered, and when present materially affected the power of walking.

It was possible to distinguish two types of sensory disturbance.

In the first, and more common form, the sensory phenomena were curiously patchy in distribution, being limited to certain areas of one or other limb-usually some part of the antero-external aspect of the leg or the dorsum of the foot. In two cases the upper limb was the seat of sensory changes, the lower limbs being entirely unaffected.

In the second form, of which only three examples were seen, the disturbance of sensibility was distributed on the legs and feet in a symmetrical manner, and bore an exact resemblance to that encountered in the ordinary type of multiple neuritis. 


\section{THE TENDON REFLEXES.}

An examination of the tendon reflexes of the lower limbs was found to be a convenient guide in the search for neuritic symptoms. their depression or absence being an almost certain indication of the coexistence of sensory disturbances. None the less, in a few cases the knee or ankle jerk was found to be abolished, although the extremities were otherwise normal.

Such a finding may perhaps be legitimately regarded as an early and slight manifestation of a neuritic process, resembling in this and other features the neuritis of diabetes, diphtheria and chronic absinthe poisoning.

As will be seen from Table $I$, an exaggeration of the deep reflexes was a common finding in the whole series and appeared to have no special significance, but it is interesting to note that the knee and ankle

TABLE I.

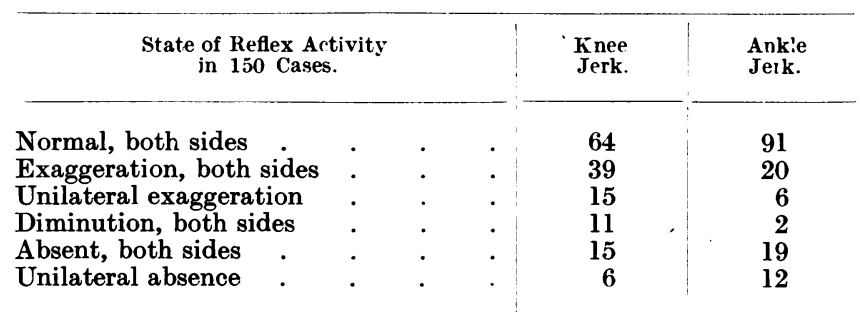

jerks were markedly exaggerated in ten cases in which sensory changes were present in the lower limbs. But even more remarkable was the curious tendency for the loss of knee or ankle jerk to be confined to one limb only, the knee jerk and ankle jerk being absent on one side only in six and twelve cases respectively.

\section{ILLUSTRATIVE CASES.}

CASE I.-G., a soldier, age twenty-two, was admitted in a very debilitated and anæmic state. His gums were swollen, inflamed, and bleeding; his pulse, rapid, irregular, and of low tension. His spleen was slightly enlarged. There was no history of malaria. The lower extremities presented a wide-spread purpuric eruption; subperiosteal hæmorrhages could be seen and felt along the crests of both tibir. The patient complained of great pain in both legs, worse at night, and aggravated by the slightest movement; the duration of the affection was one month. On examination, symmetrical areas of intense hyperæsthesia to pinprick and pressure were found on both legs extending as high as the knee (Fig. 2). Over the same areas there was tactual hyperresthesia, light cotton wool touches being more readily felt than on the normal parts of the body. The skin of the affected region was tense, glazed and smooth. Movements at the ankle joints were greatly restricted owing to the tenderness of the soles and leg muscles, but apart from this a slight degree of motor weakness of the dorsiflexors of the ankles could be demonstrated. 
In walking the patient had difficulty in raising his toes from the ground, and advanced slowly and laboriously with the aid of two sticks. The knee and ankle jerks were abolished.

The second and more common type of scorbutic neuritis may be found on the upper and lower limbs, and in the distribution of the lower spinal nerve roots.

CASE II.-D., a Bulgar, was admitted with scorbutic symptoms of one month's duration. He was anæmic and debilitated, with bleeding, swollen

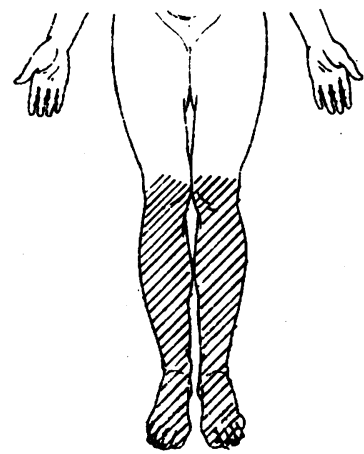

Fia. 2.

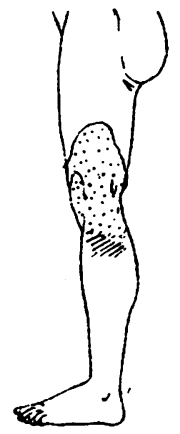

Fra. 4.

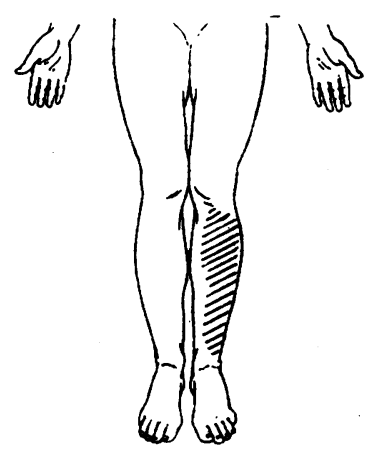

Fia. 3.

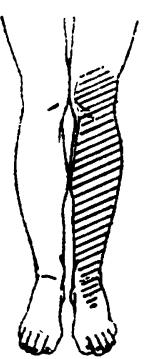

(1)
Frg. 5.

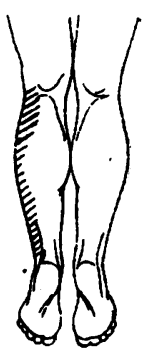

gums, and his lower limbs showed a well-marked petechial eruption. On the inner side of the left ankle there was a subcutaneous hæmorrhage of not very recent origin. The patient complained of great pain of a burning nature in the left leg which prevented his sleeping at night.

Sensory Disturbance.-On the anterior aspect of the left leg there was an area of cutaneous and deep hyperæsthesia to pinprick and pressure. Tactile sensibility was normal (Fig. 3). There was no motor weakness; the left tendo achillis had a swollen appearance. On the right side the knee and ankle jerks were normal ; on the left side the knee jerk was diminished, the ankle jerk absent.

CASE III.-V. R., a soldier, age forty, was admitted to hospital with well-marked symptoms of scurvy of two weeks' duration. He was pro- 
foundly anæmic, with swollen, ulcerated gums which bled freely. Both legs were the seat of large subcutaneous hæmorrhages; the skin had a tense, shiny appearance. The patient complained of a dull, aching pain along the anterior aspect of the left leg, which had been present for about one month.

Sensory Disturbance. - On the outer aspect of the left leg in the neighbourhood of the knee there was an area of anæsthesia to light touch. Over the same area the appreciation of two points of a compass (applied simultaneously). and of warmth and coolness was lost. Analgesia to pinprick existed over a somewhat smaller area, and a small patch of hyperæsthesia was present at the lower border of the area of tactile loss (Fig. 4). Pressure on the left peroneal nerve was very painful. There was no motor paralysis. The right knee jerk was normal; the left very much exaggerated. Both ankle jerks were brisk.

CASE IV.-K. J., a soldier, age twenty-three, was admitted to hospital

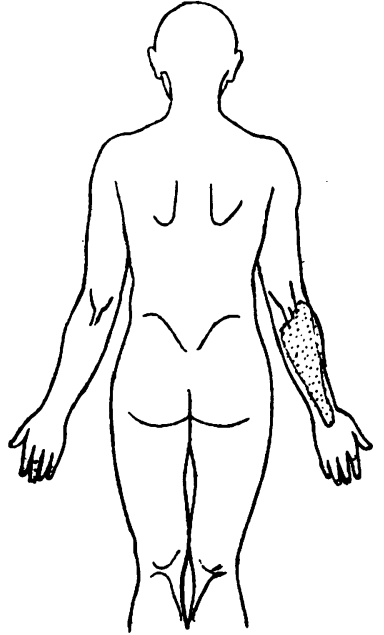

Fig. 6.
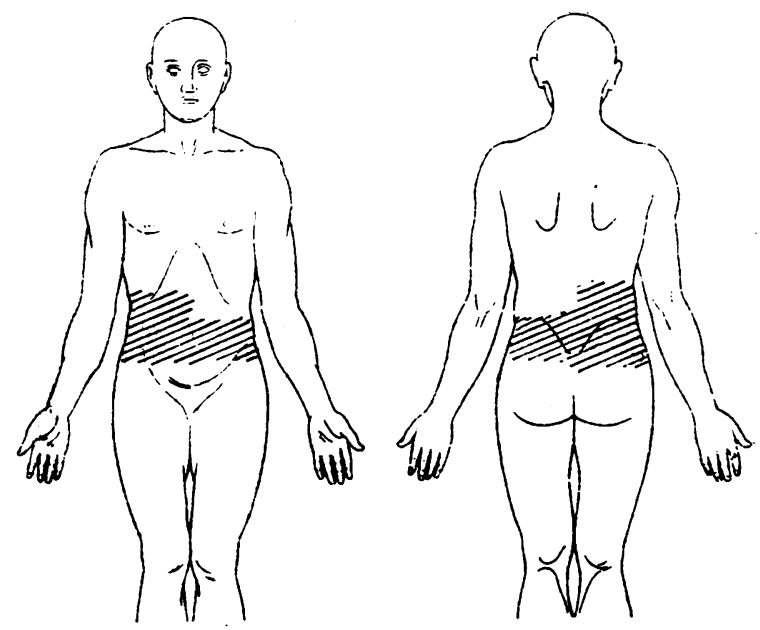

FIg. 7.

with well-marked scorbutic symptoms of two months' duration. His gums were swollen, spongy, and bled freely on slight pressure. A slight follicular eruption was present on all four limbs. The left leg was enormously swollen and œedematous; the tissues in the neighbourhood of the tibia felt firm and indurated. The cutaneous disturbance of sensibility was represented by an extensive area of hyperæsthesia to pinprick over a large area of the left leg (Fig. 5). Tactile sensibility was slightly impaired, and the threshold for the appreciation of simultaneously applied compass points raised. Over a similar area the limb was hyperæsthetic to deep pressure. There was no disturbance of motor power. The knee and ankle jerks were abolished on both sides.

CASE V.-V. M., a soldier, age thirty-two, was admitted to hospital with scorbutic symptoms of eight days' duration. His gums were pale, but showed no scorbutic change. On all four limbs there was a well-marked hæmorrhagic eruption consisting of small discrete spots of a dull tefelour,

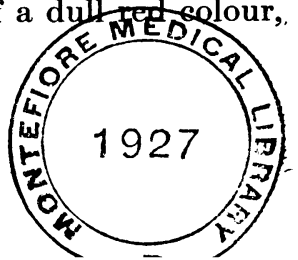


and on the extensor surface of the right forearm a deep-seated hæmorrhage could be felt, with staining of the skin over it. A few small nodes were present on the left tibia.

Sensory Changes.-These consisted of an area on the extensor aspect of the right forearm in which the appreciation of light touch and pinprick was lost (Fig. 6). The vibration of a tuning fork was not felt over the right ulna. Sensibility in the lower limbs was normal. There was no disturbance of motor power. The deep reflexes were present.

The following is an example of a type in which the neuritis symptoms were distributed in root fashion on the trunk.

CASE VI.-G., a soldier, age thirty-five, was admitted with scurvy of three months' duration. He was in a very weak state, unable to walk, and complained of intense pain in the back. Examination revealed the presence of an area of marked hyperæsthesia to light touch and pinprick, encircling the trunk, and more extensive on the right than on the left side (Fig. 7). Posteriorly it extended from the twelfth dorsal to the first sacral spinous process. There was diffuse wasting of the lower limbs and glutei. The right abdominal reflex was diminished; the left normal. The right plantar reflex gave an extensor response. The knee and ankle jerks were exaggerated on both sides; there was no sphincter trouble.

In Table II. the clinical features of twenty other cases are tabulated, information being given with regard to the duration of the disease, the cutaneous or other manifestations of scurvy, the state of the deep reflexes, and the situation of the sensory disturbances.

\section{DISCUSSION}

The symptoms outlined above tended to disappear as the general condition of the patient improved, although complaint was often made of persistent pain long after recovery from the ordinary signs of scurvy. In addition to treatment by foodstuffs rich in the antiscorbutic substance local measures were found to be useful. In early cases good results were obtained by the application of cold compresses, and in convalescent patients Bier's passive hyperæmia appeared to hasten the disappearance of the neuritic pains.

With regard to the mode of production of these symptoms, the presence of large hæmorrhagic extravasations in many subjects favoured the hypothesis that they were in part determined by pressure on peripheral nerve trunks, although this explanation cannot be advanced for the three cases in which the disturbance of sensibility was symmetrical in the two limbs. In these the neuritis can only have been toxic in origin. As the slightest bruise or injury is known to cause hæmorrhage into the injured part it is possible that trauma, acting on nerves deprived of their normal nutritive balance, may have been concerned in the production of sensory symptoms. It must also be observed that in this series the subperiosteal and intramuscular hæmorrhages were essentially 
inflammatory in character, for local heat, redness and swelling could always be demonstrated.

It is thus possible that in the production of scorbutic neuritis several factors may be concerned, and as one or other of these is the more emphasized, the neuritis may correspondingly differ in type.

TABLE II.

\begin{tabular}{|c|c|c|c|c|c|c|c|}
\hline \multirow{2}{*}{ No. } & \multirow{2}{*}{$\begin{array}{c}\text { Dura- } \\
\text { tion } \\
\text { of } \\
\text { Symp- } \\
\text { toms } \\
\text { in } \\
\text { Days. }\end{array}$} & \multicolumn{2}{|c|}{ Knee Jerks. } & \multicolumn{2}{|c|}{ Ankle Jerks. } & \multirow{2}{*}{$\begin{array}{l}\text { Distribution } \\
\text { of Sensory } \\
\text { Change. }\end{array}$} & \multirow{2}{*}{ Manifestations of Scurvy. } \\
\hline & & R. & L. & R. & L. & & \\
\hline 1 & 20 & +++ & $\mathbf{n}$ & +++ & $\mathrm{n}$ & $\begin{array}{l}\text { Right leg } \\
\text { and hand. }\end{array}$ & $\begin{array}{l}\text { Gums spongy ; cutaneous mani- } \\
\text { festations slight. }\end{array}$ \\
\hline 2 & 30 & +++ & +++ & + & + & Right leg. & $\begin{array}{l}\text { Gums bleeding; large sub- } \\
\text { cutaneous hæmorrhages right } \\
\text { leg; nodes left tibia. }\end{array}$ \\
\hline 3 & 35 & +++ & $\mathbf{n}$ & +++ & $\mathbf{n}$ & $\begin{array}{l}\text { Right leg } \\
\text { and foot. }\end{array}$ & Edema and swelling right leg. \\
\hline 4 & 30 & $\mathrm{a}$ & $\mathrm{n}$ & a & $\mathbf{n}$ & $\begin{array}{l}\text { Right ankle } \\
\text { and foot. }\end{array}$ & $\begin{array}{l}\text { Gums inflamed ; hæmorrhages } \\
\text { right knee and ankle; folli- } \\
\text { cular eruption skin. }\end{array}$ \\
\hline 5 & 35 & a & a & a & a & Both legs. & $\begin{array}{l}\text { Gums slightly spongy; œedema } \\
\text { of ankles. }\end{array}$ \\
\hline 6 & 56 & +++ & +++ & +++ & $+t+$ & $\begin{array}{l}\text { Right leg } \\
\text { and foot. }\end{array}$ & $\begin{array}{cc}\text { Gums bleeding; } & \text { hæmorrhage } \\
\text { soft palate } ; & \text { subperiosteal } \\
\text { nodes left tibia. } & \end{array}$ \\
\hline 7 & 56 & $\mathbf{n}$ & +++ & $\mathbf{n}$ & $++t$ & Left leg. & $\begin{array}{l}\text { Gums bleeding; extreme } \\
\text { asthenia; intramuscular } \\
\text { hæmorrhages both legs. }\end{array}$ \\
\hline 8 & 84 & d & d & $\mathbf{a}$ & a & Both legs. & Gums spongy ; pain in back. \\
\hline 9 & 20 & d & d & a & a & None. & $\begin{array}{l}\text { Gums spongy ; hæmorrhage } \\
\text { right leg; petechial eruption } \\
\text { skin. }\end{array}$ \\
\hline 10 & 42 & +++ & +++ & $++t$ & +++ & Right leg. & $\begin{array}{l}\text { Gums spongy ; swelling and } \\
\text { odema right calf. }\end{array}$ \\
\hline 11 & 30 & $\mathbf{n}$ & d & $\mathbf{n}$ & $\mathrm{a}$ & Left leg. & $\begin{array}{l}\text { Gums bleeding ; petechial erup- } \\
\text { tion limbs. }\end{array}$ \\
\hline 12 & 84 & $d$ & $\mathrm{n}$ & a & $d$ & Right foot. & Gums swollen and bleeding. \\
\hline $\begin{array}{l}13 \\
14\end{array}$ & $\begin{array}{l}30 \\
40\end{array}$ & $\begin{array}{l}d \\
\text { a }\end{array}$ & $\begin{array}{l}\mathbf{n} \\
\mathbf{a}\end{array}$ & $\begin{array}{l}\mathbf{a} \\
\mathbf{a}\end{array}$ & $\begin{array}{c}\mathrm{d} \\
\mathbf{a}\end{array}$ & $\begin{array}{l}\text { Right leg. } \\
\text { Left leg. }\end{array}$ & $\begin{array}{l}\text { Manifestations slight. } \\
\text { Gums bleeding; hæmorrhages } \\
\text { both legs : swelling left calf. }\end{array}$ \\
\hline 15 & 56 & a & a & a & a & Left leg. & $\begin{array}{l}\text { Gums spongy; left leg enor- } \\
\text { mously swollen. }\end{array}$ \\
\hline 16 & 30 & +++ & $\mathbf{n}$ & $++t$ & $\mathbf{n}$ & Right leg. & $\begin{array}{l}\text { Gums slightly swollen; right } \\
\text { leg much swollen. }\end{array}$ \\
\hline 17 & 25 & d & $d$ & a & $\mathbf{a}$ & Both legs. & $\begin{array}{l}\text { Petechial eruption legs; } \\
\text { hæmorrhage right foot ; } \\
\text { subperiosteal nodes. }\end{array}$ \\
\hline 18 & 20 & d & d & d & $\mathbf{a}$ & $\begin{array}{l}\text { Right leg } \\
\text { and hand. }\end{array}$ & $\begin{array}{l}\text { Swelling right knee and left leg; } \\
\text { subperiosteal nodes. }\end{array}$ \\
\hline 19 & 30 & n & d & $\mathbf{n}$ & a & Left leg. & Gums ulcerated and bleeding. \\
\hline 20 & 30 & $++t$ & +++ & +++ & $++t$ & Right leg. & $\begin{array}{l}\text { Gums bleeding ; deep-seated } \\
\text { hæmorrhage right calf. }\end{array}$ \\
\hline
\end{tabular}

$\mathrm{n}=$ normal. $\mathrm{d}=$ diminished. $\quad \mathrm{a}=$ absent. $\quad+++=$ marked exaggeration.

REFERENCE.

A. F. Hess, Proc. Soc. Experim. Biol. and Med., 1916, xiv, 1.

voL. vi. -No. 23. 